\title{
Becoming a Confucian in Contemporary Singapore: The Case of Nanyang Confucian Association
}

\author{
Chang Woei Ong * and Khee Heong Koh
}

check for updates

Citation: Ong, Chang Woei, and Khee Heong Koh. 2021. Becoming a Confucian in Contemporary Singapore: The Case of Nanyang Confucian Association. Religions 12: 854. https://doi.org/10.3390/ rel12100854

Academic Editor: Anna Sun

Received: 31 July 2021

Accepted: 5 October 2021

Published: 11 October 2021

Publisher's Note: MDPI stays neutral with regard to jurisdictional claims in published maps and institutional affiliations.

Copyright: (c) 2021 by the authors. Licensee MDPI, Basel, Switzerland. This article is an open access article distributed under the terms and conditions of the Creative Commons Attribution (CC BY) license (https:/ / creativecommons.org/licenses/by/ $4.0 /)$.
Department of Chinese Studies, The National University of Singapore, Singapore S150115, Singapore; chskohkh@nus.edu.sg

* Correspondence: chsongcw@nus.edu.sg

\begin{abstract}
Using the Nanyang Confucian Association (NCA) as a case study, this paper explores the multi-faceted processes through which a segment of Singapore's Chinese community constructs its self-identity based on an understanding of Confucianism that dismisses its religious attributes while underscoring the ethnic and cultural dimensions. Tracing the history of the association since its formation in 1914, the paper hopes to contribute to recent overseas Chinese studies on the rethinking of the notion of the Chinese diaspora within the context of the formation, circulation, and contest of a global Chinese identity by asking the following questions: Does identifying with the Confucian tradition necessarily require one to acknowledge their connection with China? Would a self-proclaimed Confucian be perceived as someone who looks to China for ethnic and cultural affiliation and thus appears less local? The authors argue that, while still acknowledging the spatialtemporal centrality of China as the origin of Confucianism and Chinese civilization, leaders of the NCA clearly intended to simultaneously position the NCA at the center of global Confucian activism. What emerges from the processes initiated by the NCA in constructing its identity is a complex overlay of history, geography, and culture that gives rise to a vision of multiple centers.
\end{abstract}

Keywords: Nanyang Confucian Association; religion; Chineseness

On 6 October 2018, during a banquet organized by the Nanyang Confucian Association (NCA) to celebrate the 2569th birthday of Confucius and the 104th anniversary of the association, the president Kek Boon Leong (Guo Wenlong, 郭文龍) openly objected to the abolition of Section 377A of Singapore's penal code in his address to the guests. This particular section in Singaporean law titled "outrages of decency" prescribes that:

Any male person who, in public or private, commits, or abets the commission of, or procures or attempts to procure the commission by any male person of, any act of gross indecency with another male person, shall be punished with imprisonment for a term which may extend to 2 years. (The Statutes of the Republic of Singapore 2008, p. 205)

The lesbian, gay, bisexual, transgender, and queer (LGBTQ) community in Singapore, as well as their sympathizers, have, for many years, lobbied for the repeal of this law. As expected, their efforts have been met with strong pushback from some quarters of society. Although from different intellectual, cultural, and religious backgrounds, opponents of the repeal converge on the belief that abolishing the law would inevitably lead to the legalization of same-sex marriage, which would in turn destroy the primacy of the family unit and erode the foundation of human society.

Kek shares similar sentiments. However, his speech, delivered during the specific occasion in Mandarin, carried special meaning for the Chinese community, as it was seen as representing a Chinese and Confucian position. Although Kek tried to soften his militaristic tone by appealing to the public to sympathize with, and not put too much pressure on, individuals who exhibit homosexual inclination because of "physiological or psychological 
issues", his message is clear: homosexuality is abnormal and immoral, and is at odds with the natural order, heavenly principle, and human nature.

In Kek's view, the fact that homosexuality is gaining acceptance today is a sign that modern society is failing, as an increasing number of people are abusing the idea of freedom and human rights in order to pursue self-serving agendas. To combat this undesirable trend, which would eventually lead to the breakdown of morality and society, Kek urged his audience to safeguard traditional culture, as he considers that this is the only defense against the corruptive ideologies of modern society. The event and Kek's speech were reported in a local Chinese newspaper ("Renwei hui daozhi libeng yuehua: Nanyang Kongjiaohui huizhang fandui feichu 377A tiao", 認會導致禮崩樂壞: 南洋孔教會會長反 對廢除377A條, “The belief that [this] will lead to the collapse of proper rites and music: The president of Nanyang Confucian Association opposed the abolition of Section 377A", Lianhe zaobao 聯合早報, 8 October 2018. Available online: https:/ / www.zaobao.com.sg/ news/singapore/story20181008-897203 (accessed on 10 January 2021)).

By referring to the notion of traditional culture and comparing and contrasting it with modern society, it is apparent that Kek blames the modern West for spreading what he perceives as its intoxicating values. It is also clear that what Kek meant by traditional culture is Confucianism. At one point in his speech, he even invoked the phrase "libeng yuehuai" (禮崩樂, the collapse of proper rites and music) to describe what a society in disarray would look like when the principles of nature are not observed. Confucianism thus understood is a form of ethics and a social system based on a philosophy of nature that is commonly described as underpinning the Chinese way of living.

Kek's statement was met with disagreement among some members of the audience who attended the dinner, including both authors of this paper. One author who was serving as the vice president of the NCA at that time chose to resign from the post because he disagreed with Kek ("Fandui daode shenpan tongxinglian zhe, Nanyang Kongjiaohui buhuizhang Wang Changwei qingci", 反對道德審判同性戀者, 南洋孔教會副會長王昌 偉, “Opposing passing moral judgement on homosexuals, the Vice President of Nanyang Confucian Association Ong Chang Woei resigned", Lianhe zaobao 聯合早報, 11 October 2018. Available online: https:/ /www.zaobao.com.sg/news/singapore/story20181011-898059 (accessed on 11 January 2021)). The other published an op-ed article in the newspaper, rebutting Kek's understanding of Confucianism and traditional Chinese culture's attitude toward homosexuality. In the article, the author notes that all notable Confucian thinkers in the past were silent on this issue, and, historically, homosexual behaviors were recorded but tolerated throughout most of China's past. Moreover, the provision in 377A that criminalizes sexual intercourse between two men is, perhaps ironically, a legacy of British colonial rule. It is therefore absurd to cite or even claim to represent Confucianism and traditional Chinese culture in one's attack on homosexuality. If one is sincere about preserving traditional Chinese culture, the author suggested that they should support the call to repeal 377A and not the other way around (Koh Khee Heong (Xu Qixiong許齊雄], “Weihu chuantong duikang xifang”, 維護傳統對抗西方, “Safeguard tradition, oppose the West", Lianhe zaobao 11 October 2018. Available online: https:/ / www.zaobao.com.sg/ zopinions/views/story20181011-898165 (accessed on 10 January 2021)).

Several observations can be derived from this. First, the NCA, under the leadership of Kek Boon Leong, does not shy away from tackling highly controversial issues through promoting a form of Confucianism in line with its principles. This effort, in trying to stay relevant in contemporary Singaporean society where knowledge of Chinese culture and language, not to mention Confucianism, has been in decline for decades, is truly remarkable, especially considering the fact that the NCA was almost disbanded until Kek assumed the role of president in 2007. Second, the NCA's definition and promotion of Confucianism has always been situated in a discourse that seeks to underscore the contrast between traditional Chinese culture and Western values. Kek's anti-LGBTQ message is but one of the most recent displays. Third, the disagreement between Kek and the two authors of this paper reveals the tensions within the community when efforts are directed toward 
defining the true spirit of Confucianism and Chinese culture. Questions regarding who is a "real" Confucian have always been a hotly contested matter.

The second and third points, which speak to the processes of using Confucianism as a source of self-identity building, may not be unique to Singapore. In her pathbreaking book that examines the historical processes that made Confucianism into a world religion, Anna Sun provides a conceptual framework for understanding the processes of becoming a Confucian without being confined by the conventional notion of religious conversion. Although her primary focus is on China, Sun's contention that "there are many different ways of becoming a Confucian and many different ways of being a Confucian" reminds us of the importance of paying attention to the specific historical contexts when we investigate similar processes elsewhere (Sun 2013, p. 123). Indeed, However, the NCA case, as we shall see, is the product of peculiar historical circumstances that have shaped how these issues are discussed and debated. Studies on Confucianism in Singapore have mostly focused on providing a historical overview of Confucianism as a social and cultural movement (Yan 2020), or on prominent individuals associated with the movement ( $\mathrm{Li} 1990$; Yan 2017), or on the question of whether Confucianism functions as a form of religion in the Singapore context ( $\mathrm{Xu}$ 2014). In contrast, this paper attempts to examine the subject from a different perspective. To become a Confucian in Singapore often entails a resolve to exert one's Chineseness in a multi-ethnic, multi-cultural, multi-religious, and multi-lingual society. Chinese Singaporeans, whose ancestors were mainly from the southeastern coast of mainland China during the nineteenth and early twentieth centuries, form the majority of the population (about 75\%); however, the anxiety of losing their Chinese identity has persisted in some segments of the Chinese community. Does identifying with the Confucian tradition necessarily require one to acknowledge their connection with China? Would a self-proclaimed Confucian be perceived as someone who looks to China for ethnic and cultural affiliation and thus appears less local? We argue that, by focusing on the NCA's strategies and the controversies generated, we are able to provide an intriguing case for scrutinizing these issues. Such a focus can also contribute to recent overseas Chinese studies on the rethinking of the notion of the Chinese diaspora within the context of the formation, circulation, and contest of a global Chinese identity (Dirlik 2013).

Our approach and methodology are largely historical in nature; however, we are both personally involved in some of the NCA's ventures-both were commissioned by the NCA to co-author the book One Hundred Years' History of the Nanyang Confucian Association for its centennial celebration in 2014-and we do not claim objectivity. Rather, our writing is reflective and draws inspiration from a branch of ethnographic studies called "at-home ethnography", which is defined by Alvesson (2009) as:

a study and a text in which the researcher-author describes a cultural setting to which $\mathrm{s} /$ he has a 'natural access' and in which s/he is an active participant, more or less on equal terms with other participants. The researcher works and/or lives in the setting and uses the experiences and knowledge of and access to empirical material for research purposes. This research is, however, not the individual's major preoccupation, apart from the time when the empirical material is targeted for close scrutiny and writing. (Alvesson 2009, p. 159)

This paper is divided into three parts. In the first section, we provide a brief overview of the history of the NCA, with particular attention paid to how key members throughout its history pondered the religious nature of Confucianism and the related question of identity. This sets the background for the next section where we focus on the various ventures conducted by the NCA under the leadership of Kek Boon Leong; in particular, the effort to construct a Confucian temple/academy in Singapore and the protest against the decision by the Christian community in China to build a grand Protestant church in Qufu, the birthplace of Confucius. We show how the NCA tries to portray itself as a major player in the defense of what it perceives as the "real" Confucian way and authentic Chinese culture, not only in Singapore but also regionally. In the last section which also serves as the conclusion, we will draw on recent scholarship on Sinophone and Chinese diasporic 
studies to comprehend the NCA's endeavors from a cross-border perspective. Ultimately, the implication of becoming a Confucian in Singapore goes beyond the confines of the small city-state.

\section{From Straits Confucian Association to NCA}

The name Nanyang Confucian Association was formally institutionalized in 1949 when the association restarted its activities after several years of hibernation during the Japanese Occupation (1942-1945). Initially, when the association was founded in 1914 as an overseas offshoot of the original establishment founded by Chen Huan-chang 陳煥章 (1880-1933) in 1912 in Shanghai, the formal name was the Straits Confucian Association (SCA), which in Chinese is Shideli kongjiaohui, 實得力孔教會, a reference to Singapore being part of the Straits Settlements, a group of territories under British colonial rule.

The reason behind the naming and the subsequent change is worth exploring. Since the Qing Dynasty appointed its first Consul General in Singapore in 1881, the local Chinese community, who were previously treated as outlaws by the Qing government, began to gain recognition, and, in 1894, they were finally allowed to return to China legally (Lee 2013, p. 273). Prominent officials who held the post of Consul General in the late nineteenth century, including Zuo Binglong 左秉隆 (1850-1924) and Huang Zunxian 黃 遵憲 (1848-1905), spared no effort in their attempts to reconnect the Chinese community, comprising mostly business elites and laborers and few scholars and literati, with China, and to devise cultural and educational programs to promote Chinese nationalism and high culture in Singapore. Thus ensued a period when interest in Confucius' teachings soared, which led some scholars to argue that a Confucian revival movement was occurring (Yen 1976).

The founding of the SCA represented the culmination of a growing ambition among many Singaporean Chinese elites to participate in China's affairs at the national level. It was an enthusiastic response to Kang Youwei and Chen Huan-chang's call to institutionalize Confucianism as China's state religion. Yet, by naming the organization the Straits Confucian Association, leaders of the SCA clearly valued their local and British colonial identities. The first set of rules of the association, published in 1914 in both Chinese and English, stipulated in the first chapter were:

(a) To propagate and promote education, morals, and culture according to the principles of the Teacher K'ung;

(b) To advocate mutual understanding among the nations in the interests of universal peace;

(c) To assist in the diffusion of scientific and useful knowledge and acts of benevolence (Chinese Chamber of Commerce 1914, p. 1).

What is immediately noticeable in these rules is the lack of reference to Kang and Chen's endeavors in establishing a state religion. The clause about promoting and revitalizing Confucius' teachings in education, ethics, and culture appears to be situated in a decidedly secular context. However, in other chapters, there are rules for conducting proper rituals:

\section{(a) CEREMONIAL AND RELIGIOUS}

1. to hold ethical services either on a Sunday or any convenient day at places to be determined.

2. to investigate Chinese marriage customs with the view of recommending a uniformity in procedure.

3. to unify consolidate and simplify the rites in connection with religious services.

4. to make enquiry into the burial rites suitable for general observance.

5. to establish training schools or colleges for preparing preachers and for the special study of the Confucian canons and philosophy (ibid., p. 2).

The intention to emulate the practices of institutionalized religion is clear. The clauses about implementing services and setting up schools also clearly apply Christianity as a 
reference point. However, these proposals were constructed together with calls to regulate wedding and mourning rituals, an obvious indication that the leaders of the SCA saw it as their collective mission to correct, according to Confucian precepts, what they considered as prevailing undesirable customs of the local Chinese population. This mission involved demarcating the boundaries for orthodox ideology and proper institutional and ritual practices, and it invited questions regarding whether Confucianism is a form of religion and whether the SCA was a church-like organization.

Based on the rules, it is unclear what the leaders of the SCA intended concerning religion when they repetitively called for strict adherence to Confucian values and practices. A possible approach would be to examine the writings of some of the leaders. The thoughts of Lim Boon Keng 林文慶 (1869-1957), one of the founding members of the SCA and arguably its most prolific writer on Confucianism, have been well studied. Lim, who was far more proficient in the English language, understood Confucianism as representing the Chinese way of life. He essentially saw Confucius' teaching as a form of natural philosophy that is superior to Christianity or any other religion precisely because it is secular; only a Confucianism-led, secular culture could be considered to contain the essence of Chinese civilization (Li 1990; Yen 2017, pp. 403-504; Yan 2017). However, the degree of influence that Lim had on the SCA's ideological orientation and the publication of the 1914 constitution remains unknown, and it is impossible to know whether these rules were strictly observed by the members in general.

The association would be confronted by questions regarding its religious nature (or the lack thereof) throughout its history. For instance, in 1952, the renowned journalist Lien Shih Sheng 連士升 (1907-1973) wrote an op-ed in one of the leading local Chinese newspapers, questioning the name of the association. Apparently, Lien understood the term kongjiao 孔教 as referring to the "religion of Confucius." He insisted that Confucius was not the "founding patriarch" (jiaozhu 教主) of a religion but a grandmaster (dashi大師) whose contribution lies in education (Lien Shih Sheng (Lian Shi Sheng 連士升), “Xinjiapo de wenhua dongtai", 新加坡的文化動態 (Singapore's culture), Nanyang Shangbao 南洋商報, 1 January 1952. Available online: https:/ / eresources.nlb.gov.sg/newspapers/Digitised/ Article/nysp19520101-1.2.12.2 (accessed on 27 January 2021)). Lien's protest obviously did not propel the NCA to change its name; however, as we shall see later, it is an issue that the association has continued to revisit until the present day.

In some countries in regions such as Indonesia, where it is mandatory for every citizen to have a religious identity, the issue of whether Confucianism is a religion becomes entangled with the Chinese minorities' claims to citizenship (Leo 2014). In the case of Buddhism, there had been efforts led by the Peranakan Chinese monk Ashin Jinarakkhita (1923-2002) to de-emphasize its Chineseness to ensure the survival of the religion in postcolonial Indonesia when the Suharto authoritarian regime sought to introduce legislation to assimilate the Chinese Indonesian population (Chia 2020, pp. 117-53). In comparison, in both colonial and post-colonial Singapore, where one's religious identity has been independent of one's citizenship, to become a Confucian more often concerns highlighting one's Chineseness.

Yet, as an association, the SCA's formal position was not unambiguous. For instance, the opening clauses of its first published rules revealed nothing particularly Chinese or national. Instead, as seen in the second clause quoted above, it emphasizes the importance of maintaining a harmonious global environment. The third claim about supporting scientific research and philanthropic activities is also universal. In other words, although the SCA was established to aid a nationalistic cause in China, this aspect of the mission was de-emphasized in the association's most important official document. In all the chapters, the Chinese characteristics of the SCA are implicit or taken for granted. Moreover, in certain paragraphs, the drafter's (or drafters') sensitivity toward the fact that the SCA was operating in a multi-ethnic and multi-lingua society is in full display. For instance,

POLITICAL AND ECONOMIC.

1. to advocate the cause of morality temperance and humanity. 
2. to promulgate the idea of universal peace in the world.

3. to work for religious toleration, union of ethical movements, and amity and good fellowship among the races of mankind.

4. to bring to the notice of governments such social and other evils affecting our common humanity with the view of their prevention or amelioration by means of legislation (Chinese Chamber of Commerce 1914, p. 3).

In summary, from the beginning, to be a Confucian in an SCA sense would involve navigating the tension between a colonial and a national identity. However, often, this tension was downplayed or sidestepped.

The decision to change the association's formal name from SCA to NCA in 1949 reflected a shift in its self-identity. The term nanyang, which literally means the south seas, implicitly takes China as its geopolitical reference point. Along with the renaming, a new constitution was published. In the preface dated using both the Republic of China calendar and the Confucian calendar, the president Cheng Chen-wen (Zheng Zhenwen 鄭振文, 1889-1963) prescribed the mission of the association as being to promote "the surviving teaching of Confucius as well as China's indigenous ethics and scholarship" (Nanyang Confucian Association 1949a, preface).

Almost immediately after it resumed business, the NCA organized a Chinese art exhibition that sought to present the beauty of Chinese culture to the local population. In the preface to the catalogue of the exhibition, Cheng again made it abundantly clear that the NCA was a Chinese association founded on foreign land, and its mission was to reconnect the local Chinese community with their motherland and, together with 400 million fellow Chinese citizens, to show the world the beauty of Chinese culture. Cheng further provided an essentialized view of Chinese culture. According to him, Chinese culture has its origin in Confucius and survived the Mongol and Manchu invasions to continuously remain intact and constant until the present day. According to this view, the reason that the Chinese population was able to grow in number over the centuries was the resilience of this uniform and unbroken culture. Moreover, judging from how the Chinese who left the motherland and sojourned south were able to live harmoniously among other races and yet retained their own culture and customs, the power of the cultural values and teachings passed down by Confucius throughout the generations should not be dismissed (Nanyang Confucian Association 1949b, preface).

Leaving the apparent Han-centricism and oversimplified understanding of Chinese culture aside, Cheng's view is notable for its diasporic overtones that tie all Chinese people across time and space to the motherland using a notion of a Chinese culture that is supposedly timeless and boundless. This should also be understood as a response to the political and social conditions of colonial Singapore. As Bernards pointed out in his study on Southeast Asian postcolonial literature, in post-colonial Singapore and Malaya, invoking the notion of nanyang in one's literary writings did not necessarily mean an unwavering attachment to China; rather, adaptation and localization were an important part of the story (Bernards 2018). Compared with the literary writings that Bernards studied, the NCA's publications were less ambiguous in their decision to employ the term nanyang to underscore their political and cultural affiliations; however, the desire to adapt to the local conditions is equally evident.

It was only after the effort to de-colonize and establish an independent nation had been completed in the mid-1960s that the NCA finally abandoned the rhetoric of the political motherland when speaking of China. However, the term nanyang was retained, and China continued to serve as the origin of the NCA's cultural self-identity. The issue, however, was complicated by the fact that, during the Cold War era, China was a contested political entity, with two competing regimes at both sides of the Taiwan Strait claiming to represent the "real" China. Due to the geopolitical conditions of the time, the NCA's connection with "China" was mostly routed through Taiwan, even after the Chinese Communist Party had successfully lobbied for the international community to recognize it as the only legitimate government of China in the 1970s. For instance, in 1985, responding to 
the Singaporean government's plan to include Confucian ethics as a component of the compulsory religious curriculum for secondary schools, the NCA endeavored to erect a bronze statue of Confucius so that people in Singapore could have the opportunity to pay respect to the ancient sage who, as the NCA claimed, has defined the Chinese way of life for the last two thousand years. Whereas Confucianism had been criticized for being outdated and the NCA for being a group that was lagging far behind the advancement of society, leaders of the association firmly believed that Confucian ethics were beneficial to the "way of the world and man's moral law". Therefore, they "ignore(d) all obstacles and forge(d) ahead without fear or ill-will" (Nanyang Confucian Association 1985, pp. 1-7. Quotation from p. 1).

Upon learning the intent and resolve of the NCA, Chen Li-fu (陳立夫, 1900-2001), the president of Taiwan's Confucius-Mencius Society, offered to present a statue to Singapore through the Trade Mission of the Republic of China, the unofficial embassy representing the Taiwanese government. Chen was an influential political figure. He once served as Chiang Kai-shek's (1887-1975) confidential secretary as well as in several key positions in the nationalist government before 1949. When the nationalist government retreated to Taiwan, Chen relocated to the United States but returned in the late 1960s to serve as an advisor to the government and led efforts in promoting Chinese culture. Therefore, as much as it was a cultural gift, the statue was also a political gift, one that sought to establish the Republic of China, now based in Taiwan, as the only legitimate guardian of Chinese culture even as its international political status was declining rapidly.

At the time, Singapore had yet to establish official diplomatic ties with the PRC, and in the publication for commemorating the event, the NCA used "Taiwan" and "Republic of China" interchangeably (ibid, p. 1), indicating that, for some, the question of the legitimate representative of China was still unsettled. The NCA's position on the matter was intentionally ambiguous. However, at a time when the PRC was still recovering from the Cultural Revolution that was hostile toward traditional culture, the NCA's approach seemed to be less about affirming the political legitimacy of the nationalist government and more about using Taiwan's claim to authentic Confucian and Chinese culture to endorse its own claim to the same culture.

The geopolitical context in which the NCA operates today has changed drastically. However, the religiosity of the association and its definition and performance of Chineseness are still important issues that the NCA finds necessary to revisit time and again. The next section examines how the NCA, under the leadership of Kek Boon Leong, navigates its religious, ethnic, and cultural identity.

\section{Revitalizing the Confucian Calling}

Sheng Peck Choo (Sheng Bizhu 盛碧珠, 1912-2005), the only female president in the NCA's history, retired in 2001 after serving for sixteen years since 1985. She was succeeded by her son Simon Hu Key Chay (Hu Keji 胡克濟); however, Hu was not interested in the NCA. He only agreed to take on the role of president out of filial piety. Sheng was a renowned educator who served as the principal of Chung Hwa Girls' High School from 1954-1977, whereas Hu was an accomplished accountant. Unlike their predecessors, Sheng and $\mathrm{Hu}$ were not business elites with many personal resources. Unlike the Chinese Chamber of Commerce and other kin- and territorial-based associations, the NCA was never politically or socially important. It was able to continue operation for so long because of the personal calling of the business leaders who helmed the organization. Hu's reluctance to be responsible for the NCA is partly a reflection of the difficulties experienced by leaders with fewer financial means.

The NCA was also plagued by a common problem faced by many Chinese organizations since the 1980s: their declining relevance in Singaporean society, where the government, staffed mostly by English-educated political leaders, had taken over the roles that these organizations used to play in the past. In the last annual general meeting that Sheng chaired in 2000, she pointed out that members of the association were rapidly ageing 
and that there was an urgent need to recruit younger members. In the same meeting, members were asked to vote for the proposed change of the formal Chinese name of the NCA from Nanyang Kongjiaohui 南洋孔教會 to Nanyang Kongxuehui 南洋孔學會, a motion initiated by an executive committee member, Dr. Ning Ngui Ngi (Lin Weiyi 林緯毅). The difference between jiao and xue is important. In modern standard Chinese, the term jiao is often associated with the notion of religion. The term $x u e$, on the other hand, denotes "learning" or "school". The issue was important enough that an explanatory note was attached to the meeting minutes detailing the rationale for proposing the change:

It has been 84 years since the founding of our association. The objective to promote the doctrine of Confucius and develop the inherent morality in Confucianism was laid down by our former worthies, and it is through the effort of the former worthies and members that the association is able to keep growing... Nowadays, given the new social circumstance, the way of promoting Confucianism has to keep pace with the times. The name kongjiaohui may leave a religious or didactic impression on the public. Therefore, people, especially the young generations, often mistook it for a religious institution and stay away from us.

Now, we would like to change the name to kongxuehui, which conveys the meaning of "scholarship" and "learning". This will help to attract scholars and academics to join our association. In a religious form and without dynamic scholarship, kongjiaohui will not contribute to the construction of our country's culture and the promotion of [research] on Confucianism and Chinese intellectual history. Moreover, it will obstruct the future development of our association.

In order to keep pace with the development of the country and the civilization of the society, we hope to seek the support of our members to change the Chinese name of our association from Nanyang kongjiaohui to Nanyang kongxuehui (NCA AGM meeting minutes, 25 March 2000).

The proposal was clearly targeting young people who were under the "wrong" impression that the NCA was a religious institution whose mission was to spread Confucianism as a form of religion and thus refused to join the association. By proposing to replace jiao with $x u e$, it hoped to underscore its scholarly and academic attributes and remove all traces of its religious identity. Several years later, a similar view was expressed by Shu Sinn Whor (Su Xinwu 蘇新淦), a committee member and a highly respected academic who taught Confucianism and Chinese philosophy at the National University of Singapore before he retired. Shu was quoted in the media as saying that the real meaning of the character jiao in the Chinese name of NCA means moral education, not religion ("Jiren lixia jin shiji zhongyou huisuo, Nanyang Kongjiaohui jiang tanjing lunshi”，寄人篗下近世紀終有會 所，南洋孔教會將談經論史 (Lodging under someone else's roof for almost a century, the Nanyang Confucian Association will finally have a clubhouse, they will discuss Confucianism and history), Lianhe zaobao 聯合早報, 6 June 2008). However, because a quorum was not present during the meeting, no vote was cast, and the original name remained. Yet, the issue of religious identity was only temporarily suspended; it resurfaced in 2004 when the NCA proposed establishing a shrine to commemorate Confucius and setting up a working committee internally to manage the project. The plan did not materialize, as the working committee was disbanded in 2006 before any action was taken. However, suggestions provided during the meeting about how the shrine should be named still shed light on how the NCA perceived its own identity and mission. Three possible names were considered: Confucius Temple (Kongmiao 孔廟), Confucius Palace (Kongsheng dian 孔聖 殿), and Confucius Hall (Kongsheng tang 孔聖堂). Eventually, the last one, which appears the least religious, was selected, and the suggested English name was Confucius Hall, Singapore (Xu 2010, pp. 219-20).

Again, after Simon Hu stepped down and Kek was elected as the president in 2007, the latter immediately revisited the idea. During the 2009 annual general meeting, Kek announced that he would be petitioning the government to build a Confucian temple. He reasoned that, in any dialogue between the various civilizations and the pursuit of harmony, 
Confucianism must occupy a key position. However, Singapore did not have a building named after Confucius to promote Confucianism. Therefore, as the most-established Confucian society in Singapore, the NCA must shoulder the responsibility to create a monument in the name of Confucius. It was announced in the annual general meeting of the following year that the formal name of the building would be changed to The Supreme College of Confucius (Kongzi daxudetang 孔子大學堂).

The planned establishment was unmistakably, among other things, a site for worship. It was modeled after the setup of the state school system in late imperial China where a shrine for worshipping Confucius and other state-recognized Confucians was integrated into the compound (“Kongzi daxuetang choujian jihuashu”, 孔子大學堂籌建計 劃書 (Proposal for Establishing The Supreme College of Confucius), NCA internal document, 9 December 2009). Yet, the NCA insisted that this was non-religious. The change in the name to the Supreme College of Confucius was decided in line with the NCA's self-identification that it was not a religious sect and should not be seen as one.

Here, the distinction made by Anna Sun between explicit and implicit religious identities is useful in helping us think through the NCA's self-identification. According to Sun:

Explicit religious identity is the self-avowed identification of individuals with a specific religious tradition (in rare cases, multiple religious traditions). Explicit religious identity is manifested in people who recognize and acknowledge one or more religious traditions as central to their identity and to their conception of a meaningful life. Implicit religious identity, on the other hand, is salient in people who practice various religious rituals, beliefs, and ethics that are significant or even central to their identity and conception of a meaningful life, yet they do not necessarily acknowledge it as the source of a religious identity for cultural, historical, social, or political reasons. (Sun 2020, p. 216)

The way in which the NCA venerates Confucius displays all the ritual elements that we would normally associate with religious practices, including the yearly onstage offering of flowers, fruits, and alcohol performed to the tune of specially crafted eulogy during banquets organized to celebrate Confucius' birthday. However, the NCA has always maintained that Confucianism is not religious in nature. Although it is tempting to classify such self-definition as the manifestation of an implicit religious identity, we argue that the explicit rejection of religious identity warrants greater attention in this case. In this regard, Sun's call to examine the "cultural, historical, social, or political reasons" closely is important.

As observed in the early phases of the association's history, the NCA was constantly confronted with questions regarding its religious identity. During the New Cultural Movement in the 1920s (commonly known as the May Fourth Movement), when increasing numbers of Chinese intellectuals were persuaded that China's backwardness could be attributed to the lack of scientific spirit in its traditional culture, religion was often condemned for being superstitious and obstructing the nation's quest for modernity. The May Fourth conception of the division between science and religion was introduced into Singapore by political activists, educators, and writers from China, and internalized by the local Chinese who were exposed to such ideas via a variety of channels over the course of the first half of the twentieth century. How the NCA has defended its secular identity until the present day underscores the lingering effect of the May Fourth vision on Chinese-educated Singaporeans.

The vision of constructing a physical building for the Confucius college never materialized. Instead, it was announced almost ten years later, in 2020, that the college would serve as a kind of virtual umbrella for branding talks, classes, reading groups, seminars, lectures, and other educational endeavors such as publishing pedagogical materials undertaken and organized by the NCA ("Kongjiaohui chengli Kongzi daxuetang ban jiangzuo bian jiaocai", 孔教會成立孔子大學堂辦講座編教材 (Nanyang Confucian Association establishes The Supreme College of Confucius, organises lectures and compiles teaching materials), 
Lianhe zaobao 聯合早報, 13 October 2020). The change in plan underscores the difficulty faced by the NCA in carrying out its mission without the enthusiastic support from both the government and society at large.

Kek's original plan was to hold a groundbreaking ceremony unveiling the building in 2011 in conjunction with the World Chinese Entrepreneurs Convention, which was scheduled to be held in Singapore that year. This would have allowed Singapore to establish itself as the center of global Chinese culture (Xu 2010, pp. 219-20). This idea is notable for its affiliation with business culture. Announcing the intention to showcase the NCA's cultural mission at a major international business convention highlighted the organization's tradition of having business elites as its leaders, as well as Kek's fundraising strategy. More importantly, for Kek and key members of the NCA, to be a Confucian in Singapore is first and foremost about reclaiming one's Chinese identity in a country where Confucius is not even afforded a proper monument, and promoting Confucianism in an international convention allowed the NCA to exert its Chineseness without having to look to China to take the lead.

However, the homeland of Confucianism remains important. In 2010, it was suddenly announced that a Trinity church would be built in Qufu, the home of Confucius, only about three kilometers away from the Confucian temple. The planned Gothic-style building was supposed to be one of the largest churches in the world. It would occupy a plot of land of about 400 square meters with a height of $42 \mathrm{~m}$ and have 3000 seats. Its magnitude would outshine the Confucian temple (Yang 2013).

The announcement caused an instant uproar within the Confucian community. Ten prominent scholars of Confucianism (including one from Taiwan) penned an open letter criticizing the plan and called for the government to ban the construction ("Zunzhong Zhonghua wenhua shengdi, tingjian Qufu Yejiao jiaotang: guanyu Qufu jianzao Yejiao dajiaotang de yijianshu", 尊重中華文化聖地, 停建曲阜耶教教堂: 關於曲阜建造耶教大 教堂的意見書 (Respect the holy land of Chinese culture and stop the construction of Christian cathedral in Qufu: Opinion on the construction of a Christian cathedral in Qufu), 22 December 2010. Available online: https://www.rujiazg.com/article/1655 (accessed on 20 February 2021). They saw it as a deliberate move to challenge the orthodoxy of Confucianism, which they insisted is the heart of the Chinese civilization. They asked the following rhetorically: What would Christian devotees think if we built a huge Confucian temple in Jerusalem or the Vatican? Would the government and the local people allow it? Implicit in this line of argument is the assumption that the Confucian (read, "Chinese") way of life is threatened by an aggressive foreign civilization. The core of the issue is not about clashes of religion per se, but about defending the national culture. The letter writers made it clear that they are not against religious freedom, but the offence caused by this move from the Christian community needed to be made clear as the writers perceived it as intended to hurt the national feelings of the Chinese in China and overseas.

The countersuggestion by the church to include in the plan a Christian-Confucian exchange center did not satisfy the protestors. An increasing number of individuals and organizations in China and overseas joined the protest and signed the letters. Due to the strong opposition, the construction was suspended indefinitely. At the time of this writing, it is unclear whether the plan will ever proceed.

The NCA was a fervent participant in the protest. In addition to signing the letter in his capacity as the president of the NCA, Kek wrote another letter echoing the main points of the original letter, but also offered something new. He recounted the history of China's encounter with Christianity and paralleled it with Buddhism's historical experiences. He predicted that, just as Buddhism had enjoyed great development during the Periods of Division when politics and society were in disarray but had to submit to and be absorbed into the revitalized Confucianism during the Tang-Song period, Christianity's fate in China would be similar. In the past century when the Chinese were busy attacking their own tradition and culture, Christianity helped with philanthropic causes. For this reason, anyone who loves China and the Chinese culture, Kek maintains, should try to appreciate 
Christianity and work to integrate it into Chinese culture. He therefore supports the Christian community's wish to build more churches in China.

Yet, Kek strongly opposes the decision to build a church in Qufu, especially near the Confucian temple. The symbolic value of Qufu as the homeland of Confucianism must be guarded at all cost. Although Kek maintained that China should welcome and embrace Christianity, he emphasized that this must be undertaken in a way that can help to enrich, not undermine, Chinese culture with Confucianism as its core. Chinese civilization is known to be inclusive, however, being inclusive does not mean surrendering. In this view, no foreign element should be allowed the opportunity to destroy the foundation of Chinese civilization (Kek Boon Leong (Guo Wenlong 郭文龍) 23 January 2011. “Buyi zai Shangdong Qufu shi jianzao jidujiao dajiaotang", 不宜在山東曲阜市建造基督教大教堂 (It is not suitable to build a Christian cathedral in Qufu City, Shandong Province). Available online: https:/ / www.rujiazg.com/article/1890 (accessed on 21 February 2021)).

Historians would probably disagree with Kek's analysis of Chinese history. But the more important point here is that Kek's identity as a Singaporean citizen did not stop him from speaking as if he were a Chinese national. Kek seems to imply that any person who is ethnically Chinese should stay true to their Confucian roots. Once the person is able to do that, they will have the rights to make their opinions of cultural matters in China known and counted. Kek's logic promotes the position that becoming a Confucian in Singapore would give one a legitimate role in helping China to advance its traditional culture. In this way, identifying with Confucianism is thus akin to acquiring a cultural passport that allows one to enter the Chinese nation.

Kek's call to embrace Christianity and any other foreign religion as long as they do not threaten the Chinese cultural core is also worth noting. In many instances, one who identifies with Confucianism will have little qualms accepting that a Confucian can be a Buddhist, Christian, or Muslim concurrently. This point is, however, absent from the original letter penned by the ten scholars. Kek's strategy was to highlight this understanding of Confucianism to soften the combative tone and underscore its inclusiveness; this is probably a reflection of his understanding of the NCA's own history and vision. The NCA's inclusiveness has always allowed people with varied religious orientations to be part of the organization. For instance, the former president Sheng Peck Choo was a devoted Christian. Jaffar Kassim (Chinese name Ye Yahua 耶亞華), a Malay Muslim who graduated from the Chinese department of the former Nanyang University, is a longtime serving committee member of the NCA. Ravi Sarma (Chinese name Lawei Shaerma 拉維沙爾瑪), an Indian who spent many years in China and went to college there, also served on the committee for several years. Both spoke flawless Mandarin, and they were often called upon to make speeches during the NCA's events, much to the admiration of the audience who were predominantly, if not exclusively, Chinese.

The NCA has also been providing scholarships to undergraduate students enrolled in courses on Chinese philosophy and to graduate students who choose Chinese philosophy as their research topic at two local universities (the National University of Singapore and Nanyang Technological University) since 2010. The award ceremony is held annually in conjunction with the banquet organized in celebration of Confucius' birthday. Representatives of the scholarship recipients provide speeches in Mandarin although some-especially those from an English-speaking family background and those who read the courses taught in English-clearly struggled with the language. In 2020, the graduate student recipients included Caucasians, and they were prominently featured in the newsletters published by the association. This sort of public performance can be analyzed as being intended to show the supreme but inclusive nature of Confucianism and, by extension, of Chinese culture.

In short, the NCA's portrayal of Confucianism is closely linked to the assumption that Confucianism is non-religious in nature and is therefore capable not only of tolerating but also of absorbing all other religions. It is also an explicit performance of ethnic and cultural identity that underscores the resolve to defend traditional culture and national dignity without having to declare political loyalty to the PRC. 


\section{Conclusion: Multiple Centers in a Chinese Diasporic Framework of Identity Construction}

The NCA was founded in 1914 in response to a nationalistic call in China seeking to enshrine Confucianism as a state religion. Over the next century, its religiosity was often put on trial by the public and even by its own members. This was a direct consequence of how religion was negatively perceived in modern China by radical intellectuals who strove to discard religion to pave the way for the introduction of Western science into China. In the mind of these intellectuals, to be religious is to be superstitious. Such hostility toward religion entered the minds of the overseas Chinese communities where the writings of these intellectuals were widely circulated and read. In multi-ethnic and multi-cultural Singapore, where the preservation of Chinese culture was a major concern for many Chinese, the consensus seemed to be that Confucianism should only be promoted as the core of Chinese culture if it is considered a secular system of thought. In other words, Singapore's local conditions steered the discussion about Confucianism's religiosity in a different direction. Here, the main point concerned constructing a Chinese identity suitable for a multi-ethnic and multi-cultural society under colonial rule.

The SCA's mission seems to confirm an observation made by Shu-mei Shih when she introduced the term "Sinophone studies" to the field of modern Chinese literature, indicating its viability as an approach to understanding the history and culture of overseas Chinese communities. She argued that, in the conventional usage and imagination, "Chinese" culture and language have almost always meant Han culture and standard Mandarin, while other ethnicities, cultures, and languages within the contemporary boundaries of China are often marginalized. A direct consequence of such rendering of Chineseness is the imposition of a uniform Chinese identity onto people of Chinese descent around the world, crystallized in the concept of the "Chinese diaspora". Ultimately, scholars of Chinese emigration tend to reinforce this conception in their research and ignore the particularities of specific time and space.

The remedy, Shih contends, should begin with recognizing that the construction and imagination of a uniform Chinese identity based on the notion of nationality cannot do justice to historical realities because "Sinophone people", as she terms them, have been settling in various parts of the world as locals long before the idea of the nation began to gain traction in modern times. She therefore calls on scholars to acknowledge that people who use Sinitic languages may not necessarily trace their roots to China, accept a hegemonic Chinese identity, or see themselves as being displaced from the center. Instead, a more productive approach would be to "decenter" China and consider how Chinese around the world adopt strategies to adapt and localize (Shih 2010).

However, Shelly Chan argued that, while the concept of the Chinese diaspora has been challenged in recent scholarship on overseas Chinese by Shih and others, it is still useful in depicting certain phenomena observable in specific historical moments that brought to the forefront the multifaceted relations overseas Chinese communities have had with their homeland, both real and imagined. The existence of these "diaspora moments" prominent instances that occurred over a longer "diaspora time" - calls into question the viability of nation-based historical analysis and challenges the conventional narrative about national history that is built on the assumption of a linear time. Paying attention to these diaspora moments may help us gain a richer but messier picture of China's national history.

Using Lim Boon Keng as a case study, Chan examined how ties to the Chinese roots were invoked by Lim in the 1890s and 1920s to engage with forces of colonialism, imperialism, and nationalism. In the 1990s, Lim's legacy was, in turn, celebrated by Singapore's politicians and Chinese-educated intellectuals and academics to underscore what they believed was Lim's trademark: biculturalism. The reframing of Lim occurred at a time when the state was looking for methods to promote an essentialized version of "Asian values" to combat what they saw as the adverse influence of Western liberal ideas and to reestablish diasporic ties with China amid the imminent rise of the superpower. As such, Chan contended that we should not dismiss attempts by the Chinese outside of 
China to rekindle connection with their ancestral homeland for various ends in specific moments simply because studies of the Chinese diaspora in the past have helped to create an essentialized notion of Chineseness (Chan 2015, 2018, pp. 75-106).

The founding of the SCA in 1914 points to a specific diasporic moment when Singapore's Chinese community was activated to support a movement to establish a state religion in China. Its endeavors in the late 1940s and early 1950s may also be seen as part of a larger story that reflects another diasporic moment during which processes of decolonization in Southeast Asia were changing the dynamics between China and the Chinese in some fundamental ways. How the NCA highlighted its connection with China revealed the urgency it attached to constructing a national identity based on a diasporic idea of nationhood in a time when the legitimacy of British colonial rule was repeatedly challenged.

However, this diasporic idea, founded on a reductionist discourse of Confucianism and Chinese culture, was often entangled with contesting views regarding the religiosity of Confucianism and the NCA. For some, such as Lien Shi-sheng, whether the NCA's claim to represent Confucianism could be accepted depends on the degree of its secularity. Judging from the constitution published in 1949 and the art exhibition organized by the association in the same year, the NCA seemed to have no intention of turning Confucianism into a religion, at least not in the way Lien would have understood the term. This strategy of de-religionalization continues to be crucial for the NCA to pitch the idea that Confucianism is the core of Chinese civilization to its Singapore audience.

From the 1950s to the 1980s, another complication arising from exerting one's connection with China was related to the geopolitical environment of the Cold War era. The question regarding who truly represented the Chinese state and served as a guardian of the Confucian and Chinese way was opened to contestation. In 1985, the PRC was already recognized as the rightful government of China by the United Nations but had yet to establish formal diplomatic ties with Singapore. By accepting a statue of Confucius from Taiwan's Confucius-Mencius Society and acknowledging Taiwan as a Republic of China in formal publication, the NCA essentially (and perhaps deliberately) left the question concerning political legitimacy unsettled while still seeing itself as an overseas protector and advocate of Confucianism whose value system has remained constant since it originated in China thousands of years ago.

This episode in the NCA's history confirms Shelly Chan's assertion that to acknowledge the existence of diasporic moments does not require us to assume that all Chinese overseas - past and present, far and near-shared the same ideas about China or Chinese culture. Quite the opposite, paying attention to how overseas Chinese communities produce narratives about China being the homeland of a timeless and unchanging Chinese culture can allow us to unpack the political, social, and cultural dynamics in specific tempo-spatial settings that help to create these essentialized notions of the Chinese nation.

Under Kek's leadership, the NCA embarked on an ambitious journey to revive Confucianism and promote it as the core of Chinese culture. Its efforts coincided with the rise of China in the geopolitical context; however, continued challenges are also obvious as many younger Chinese Singaporeans now lack the language competency or interest to have an in depth appreciation of this aspect of Chinese culture. Moreover, as we have seen from Kek's disagreement with the authors of this article over the LGBTQ issue, the exact meaning of being a Confucian and a self-proclaimed defender of Chinese culture is a question that opens itself to different interpretations and contestation. However, this has not stopped the NCA from being proactive in promoting an essentialized idea of Confucianism and underscoring its Chinese roots in relation to China as its cultural motherland in all of its formal endeavors. The efforts to establish a Confucian temple/academy and the Qufu saga represent two specific moments when the association's leadership sought to take the lead in defining and shaping Confucianism and Chinese culture not only locally but also for a worldwide Chinese audience. 
Shelly Chan's call for a recognition of the diasporic mentalities of Chinese emigrants in specific moments has provided a new analytical framework for depicting the historical processes through which China was changed by the mass emigration of the Chinese people overseas. Her approach is therefore China-centric and justifiably so because of the research questions she asks. The NCA's history shows that Shu-mei Shih's insistence on the importance of localization within global and diasporic Chinese experiences is an equally important reminder. However, localization can also occur alongside continued attachments to the cultural motherland. More importantly, this adds another dimension to our understanding of the center when considering diasporic groups. While still acknowledging the spatial-temporal centrality of China as the origin of Confucianism and Chinese civilization, Kek clearly intended to simultaneously position the NCA at the center of global Confucian activism. Ultimately, what emerges from the processes initiated by the NCA in constructing its identity is a complex overlay of history, geography, and culture that gives rise to a vision of multiple centers.

Author Contributions: Conceptualization: C.W.O. and K.H.K.; writing: C.W.O. and K.H.K. All authors have read and agreed to the published version of the manuscript.

Funding: This research received no external funding.

Institutional Review Board Statement: Not applicable.

Informed Consent Statement: Not applicable.

Conflicts of Interest: The authors declare no conflict of interest.

\section{References}

Alvesson, Mats. 2009. At-home Ethnography: Struggling with Closeness and Closure. In Organizational Ethnography: Studying the Complexity of Everyday Life. Edited by Sierk Ybema, Dvora Yanow, Harry Wels and Frans Kamsteeg. London: Sage Publications Ltd., pp. 156-74.

Bernards, Brian C. 2018. Writing the South Seas: Imagining the Nanyang in Chinese and Southeast Asian Postcolonial Literature. Seattle: University of Washington Press.

Chan, Shelly. 2015. The Case for Diaspora: A Temporal Approach to the Chinese Experience. Journal of Asian Studies 74: 107-28. [CrossRef]

Chan, Shelly. 2018. Diaspora's Homeland: Modern China in the Age of Global Migration. Durham: Duke University Press.

Chia, Jack Meng-tat. 2020. Monks in Motion: Buddhism and Modernity Across the South China Sea. Oxford: Oxford University Press.

Chinese Chamber of Commerce. 1914. The Rules of the Straits Confucian Association. Singapore: Chinese Chamber of Commerce.

Dirlik, Arif. 2013. Literary Identity/Cultural Identity: Being Chinese in the Contemporary World. MCLC Resource Center Publication. Available online: https://u.osu.edu/mclc/book-reviews/literary-identity/ (accessed on 8 October 2021).

Lee, Khoon Choy. 2013. Golden Dragon and Purple Phoenix: The Chinese and Their Multi-Ethnic Descendants in Southeast Asia. Singapore: World Scientific.

Leo, Suryadinata. 2014. State and "Chinese Religions" in Indonesia: Confucianism, Tridharma and Buddhism during the Suharto Rule and After. In After Migration and Religious Affiliation: Religions, Chinese Identities and Transnational Networks. Edited by Chee-Beng Tan. Singapore: World Scientific, pp. 19-42.

Li, Yuanjin 李元瑾 (Lee Guan Kin). 1990. Lin Wenqing de sixiang: Zhongxi Wenhua de Huiliu yu Maodun林文慶的思想: 中西文化的匯 流與矛盾 [Lin Wenqing's Thought: Confluence and Contradiction of Chinese and Western Culture]. Singapore: Singapore Society of Asian Studies.

Nanyang Confucian Association. 1949a. The Rules of the Nanyang Confucian Association. Singapore: Nanyang Confucian Association.

Nanyang Confucian Association. 1949b. Zhongguo Wenwu Zhanlunhui Teji中國文物展覽會特輯 [Special Issue of China Cultural Relics Exhibition]. Singapore: Nanyang Confucian Association.

Nanyang Confucian Association. 1985. Special Issue in Commemoration of the Opening of the Bronze Statue of Confucius. Singapore: Nanyang Confucian Association.

Shih, Shu-mei. 2010. Against Diaspora: The Sinophone as Places of Cultural Production. In Global Chinese Literature. Edited by Jing Tsu and David Der-wei Wang. Leiden: Brill, pp. 29-48.

Sun, Anna. 2013. Confucianism as a World Religion. Princenton and Oxford: Princeton University Press.

Sun, Anna. 2020. To be or Not to be a Confucian: Explicit and Implicit Religious Identities in the Global Twenty-first Century. In Chinese Religion Going Global. Edited by Nanlai Cai, Giuseppe Giordan and Fenggang Yang. Leiden: Brill, pp. 210-35.

The Statutes of the Republic of Singapore. 2008. Singapore Statutes Online Plus. Available online: https://sso.agc.gov.sg/Act/PC1871? ProvIds=pr377A- (accessed on 10 January 2021). 
Xu, Liying 徐李穎. 2010. Cong huaguo piaoling dao xianghuo dingsheng: Xinjiapo rujiao zai minjian fazhan de sanzhong moshi從花果 飄零到香火鼎盛: 新加坡儒教在民間發展的三種模式 [From fall to rise: The three models of the development of Confucianism in Singapore]. In Bie qi wei zong: Dongnanya de ruxue yu kongjiao別起為宗: 東南亞的儒學與孔教 [Establishing a Separate Branch of Transmission: Confucian Learning and the Confucian Religious Sect in Southeast Asia]. Edited by Weiyi Lin 林緯毅 (Ning Ngoi Ngi). Singapore: Singapore Society of Asian Studies, pp. 210-29.

Xu, Qixiong 許齊雄 (Koh Khee Heong). 2014. Kongjiao shi yizhong shenme zongiia? Shideli Kongjiaohui de ziwo renshi 孔教是一種 什宗教? 實得力孔教會的自我認識 [Is the Kongjiao a Religion? The Self-Identity of the Straits Confucian Association]. Nanyang xuebao南洋學報. [Journal of the South Seas] 68: 119-134.

Yan, Chunbao 嚴春. 2017. Taxiang de Shengren: Lin Wenqing de Ruxue Sixiang他鄉的聖人: 林文慶的儒學思想 [A Sage from Afar: Lim Boon Keng's Confucianism]. Guilin: Guangxi Daxue Chubanshe.

Yan, Chunbao 嚴春. 2020. Xinjiapo ruxue shi. 新加坡儒學史 [A History of Confucianism in Singapore]. Guilin: Guanxi Daxue chubanshe.

Yang, Li 楊莉. 2013. Qufu jiaotang diaocha baogao ji fenxi曲阜教堂事件調查報告及分析 [Investigation Report and Analysis of Qufu Church Incident]. Yuan Dao原道 [Origin of the Way] 20: 55-72.

Yen, Ching-Hwang. 1976. The Confucian Revival Movement in Singapore and Malaya, 1899-1911. Journal of Southeast Asian Studies 7: 33-57.

Yen, Ching-Hwang. 2017. Ethnicity, Personalities and Politics in the Ethnic Chinese Worlds. Singapore: World Scientific. 